EVALUASI. Vol 2. No.2, September 2018 P-ISNN 2580-3387

E-ISSN 2615-2886

\title{
PEMBENTUKAN KARAKTER SISWA MELALUI PENDIDIKAN BERBASIS PONDOK PESANTREN
}

\author{
Miftachul Ulum \\ Institut Pesantren Sunan Drajat Lamongan \\ drajatulum@gmail.com
}

\begin{abstract}
Abstrak
Kehadiran kiai sebagai penjaga keutuhan , konsistensi pendiriannya, watak dan ideologi kyai menyatu dengan kelembagaan pesantren, maka dalam pesantren konsistensi dan petuah dari seorang pengasuh menjadi sumber pengambilan keputusan. Pengasuh menjadi sumber dan magnet bagi santri untuk selalu patuh dan tunduk dalam kehidupan dilingkungan pondok pesantren. Santri hidup dan berkembang menjadi bernilai karena telah ditempa dengan kegiatan dan lingkungan yang terpatri dalam jiwa santri. Terbentuknya kultur khas pesantren inilah yang membedakannya dengan sistem pendidikan di luar pesantren yang meliputi nilai keikhlasan, nilai kesederhanaan, nilai kemandirian, nilai persaudaraan yang dilandasi oleh semangat agama dan nilai kebebasan. Santri melakukan kegiatan dari bangun tidur dipagi hari sampai menjelang akan tidur, santri telah ditempa dengan aktifitas yang selalui bernilai sehingga karakter santri atau siswa pun terbentuk. Pendidikan karakter merupakan penanaman kebiasaan (habit) tentang hal-hal yang baik dalam kehidupan, sehingga seseorang memiliki kesadaran dan pemahaman yang tinggi, serta kepedulian dan komitmen untuk menerapkan kebajikan dalam kehidupan sehari-hari. Pelaksanaan pendidikan karakter dapat dilakukan secara terintegrasi dalam setiap keseharian, baik melalui pembelajaran dikelas maupun dilingkungan luar kelas, maka hanya di pondok pesantren kegiatan tersebut lebih mudah untuk dilaksanakan, dimana siswa atau santri dapat terkontrol dengan lingkungan yang telah terbentuk.
\end{abstract}

.Kata Kunci : Pendidikan, Karakter, Pondok Pesantren

\section{PENDAHULUAN}

Berbicara tentang pesantren mungkin bukan suatu yang asing ditelinga kita, karena hampir disetiap penjuru pelosok tanah air kita sering melihat dan mudah sekali untuk menemukan pondok pesantren, apalagi diwilayah pulau Jawa. Pondok Pesantren merupakan institusi agama Islam, yang masih bercorak tradisional selain menyelenggarakan pengajaran agama juga 382 I Miftachul Ulum 
menyediakan asrama sebagai usaha untuk lebih memperdalam pelajaran agama. Istilah tradisional bukan berarti semuanya berbau kolot dan tidak menerima perubahan, bahkan penyelenggaran kegiatan setiap hari selalu meng-update dengan perkembangan teknologi. Awal berdirinya pondok pesantren mempunyai pengertian yang sederhana, yaitu tempat pendidikan santri-santri untuk mempelajari pengetahuan agama Islam di bawah bimbingan seorang Ustad atau Kyai ${ }^{1}$.

Pesantren adalah sekolah Islam berasrama yang bertujuan untuk memperdalam pengetahuan tentang Al-Qur'an dan As-Sunnah, dengan cara mempelajari bahasa Arab dan tata bahasanya Banyak hal yang menarik dari pesantren dan yang tidak terdapat pada lembaga lain adalah mata pelajaran bakunya yang ditekstualkan pada kitab-kitab salaf (klasik) yang sekarang ini terintroduksi secara populer dengan sebutan kitab kuning ${ }^{2}$. Kitab kuning diartikan sebagai buku atau kitab yang dicetak dengan mempergunakan kertas yang berwarna kuning. Sedangkan menurut pengertian istilah, kitab kuning adalah kitab atau buku berbahasa Arab yang membahas ilmu pengetahuan agama Islam seperti fiqih, ushul fiqih, tauhid, akhlak, tasawwuf, tafsir al-Qur'an dan ulumul Qur'an, hadis dan ulumul hadis, dan sebagainya yang ditulis oleh Ulama-ulama salaf dan digunakan sebagai bahan pengajaran utama di pondok pesantren ${ }^{3}$. Kesederhanaan, kearifan lokal, falsafah dan pola pendidikannya sudah mengakar pada sebagian besar masyarakat Indonesia, khususnya dalam pendidikan berbasis agama Islam yang secara tidak langsung pendidikan karakter telah ditanamkan secara kuat dengan pola dan teknik yang khas pesantren. Pendidikan karakter secara integral dalam keseluruhan proses pendidikan dan pembelajaran yang ada dalam pesantren terbentuk melalui proses keseharian Terbentuknya kultur khas pesantren yang membedakannya dengan sistem pendidikan di luar pesantren meliputi lima nilai: yakni keikhlasan, kesederhanaan, kemandirian, persaudaraan yang dilandasi oleh semangat agama, dan kebebasan ${ }^{4}$. Pembentukan karakter tidak selalu diajarkan dalam kelas, namun dilakukan secara simultan dan berkelanjutan di dalam dan di luar kelas. Keberhasilan

${ }^{1}$ Riris Nur Rohmawati, "Hubungan Antara Faktor Pengetahuan Dan Perilaku Dengan Kejadian Skabies Di Pondok Pesantren Al-Muayyad Surakarta" (Surabaya: Fakultas Ilmu Kesehatan Universitas Muhammadiyah Surakarta, 2010).

${ }^{2}$ M. Dawam Rahardjo, Pergulatan Dunia Pesantren (Jakarta: P3M, 1985). 263

Miftachul Ulum, "Eksistensi Pendidikan Pesantren: Kritik Terhadap Kapitalisasi Pendidikan," TA "LIM : Jurnal Studi Pendidikan Islam 1, no. 2 (2018): 20-37.

4 A Muchaddam Fahham, "Character Education in Islamic Boarding School," Aspirasi 4, no. 1 (2013): 29-45.

PEMBENTUKAN KARAKTER SISWA MELALUI PENDIDIKAN BERBASIS 
pendidikan karakter akan dipengaruhi oleh teladan dan contoh nyata dalam kehidupan dan dalam kegiatan pembelajaran. Pendidikan karakter tidak bisa dipaksakan, namun dijalani sebagai kehidupan keseharian sehingga dengan sendirinnya melekat kuat pada diri setiap peserta didik atau santri.

Salah satu ciri karakter dari pesantren adalah lembaga pendidikan madrasah diniyah, namun seiring perkembangan jaman pesantren saat ini tidak hanya terfokus pada madrasah diniyah sebagai lembaga non formal namun juga lembaga-lembaga pendidikan formal. Begitu juga dalam mengembangan pendekatan metode pembelajaran pesantren terus mengalami perkembangan seiring dengan kemajuan teknologi. Perkembangan teknologi telah menyentuh level dalam pengajaran baik dalam pendidikan formal maupun non formala dipesantren. Meskipun adanya modernisasi dan globalisasi dalam perkembangan teknologi, pesantren masih tetap bertahan dengan kaidah mempertahan kaidah lama yang masih baik tetapi tetap menerima pembaharuan demi kemaslahatan. Ini menunjukkan bahwa karakter pendidikan dipesantren tetap eksis dan tidak luntur oleh kemajuan dan perkembangan teknologi. Hal inilah yang menjadi dasar bahwa pesantren merupakan basis dasar dalam pembentukan karakter siswa atau santri dalam mengenyam pendidikan serta merupakan nilai kepercayaan bagi masyarakat untuk tetap percaya pada pondok pesantren.

\section{PEMBAHASAN}

\section{A. Pendidikan Karakter}

Berbicara tentang pendidikan karakter sesungguhnya tidak harus selalu diajarkan dalam kelas, tidak harus dengan kurikulum yang formal, cukup dengan hiden curriculum ${ }^{5}$. Pendidikan karakter dilakukan secara simultan dan berkelanjutan di dalam dan di luar kelas. Keberhasilan pendidikan karakter akan dipengaruhi oleh teladan dan contoh nyata dalam kehidupan dan dalam kegiatan pembelajaran. Pendidikan karakter tidak bisa dipaksakan, namun dijalani sebagai mana adanya dalam kehidupan keseharian sehingga akan dengan sendirinya melekat kuat pada diri setiap peserta didik atau santri. Pengertian karakter dapat diartikan sebagai sifatsifat kejiwaan, akhlak atau budi pekerti yang membedakan seseorang dari yang lain. Karakter bisa juga berarti tabiat atau watak, di samping itu karakter juga dapat dimaknai sebagai cara berpikir dan berperilaku yang khas tiap individu untuk hidup dan bekerja sama, baik dalam lingkup keluarga, masyarakat, bangsa, dan negara ${ }^{6}$. Lingkungan sekolah saat ini memiliki peran sangat besar pembentukan karakter siswa begitu juga dengan pesantren.

\footnotetext{
${ }^{5}$ Kamin Sumardi, "Portrait of character education in salafiah boarding school," Jurnal Pendidikan Karakter 2, no. 3 (2012): 280-292.

${ }^{6}$ Fahham, "Character Education in Islamic Boarding School." 
Peran guru atau ustad dalam dunia pendidikan modern sekarang ini semakin kompleks, tidak sekedar sebagai pengajar semata, pendidik akademis tetapi juga merupakan pendidik karakter, moral dan budaya bagi siswanya. Guru atau ustad haruslah menjadi teladan, seorang model sekaligus mentor dari siswa atau santri di dalam mewujudkan perilaku yang berkarakter yang meliputi olah pikir, olah hati dan olah rasa.

Perkembangan ilmu pengetahuan dan teknologi merupakan bagian yang juga turut penyebab perubahan siswa atau santri tetapi juga menyentuh perubahan dan pergeseran aspek nilai moral yang terjadi dalam kehidupan bermasyarakat. Beberapa kasus tawuran antar pelajar, perampokan, pembunuhan diserta mutilasi, korupsi, dan isu-isu moralitas yang terjadi di kalangan remaja seperti penggunaan narkoba dan pornografi. Konflik nilai antarbangsa sebagai dampak globalisasi sudah merupakan fenomena yang terjadi saat ini dan semakin menguat di masa yang akan datang. Globalisasi adalah suatu keniscayaan yang tidak bisa dibendungbendung lagi. Di Indonesia globalisasi sudah bisa dirasakan oleh banyak orang dari generasi tua, muda sampai anak-anak, dengan segala dampak positif ataupun negatif. Guncangan globalisasi telah menimbulkan berbagai macam krisis yang merusak citra dan rasa percaya diri bangsa. Ini merupakan situasi yang tidak kondusif untuk pembangunan, puncaknya adalah terjadinya krisis jati diri bangsa ${ }^{7}$

Kata pendidikan yang berasal dari dua kata kerja yang berbeda, yaitu, dari kata educare dan educere. Kata educare dalam bahasa Latin memiliki konotasi melatih atau menjinakkan.Jadi, pendidikan merupakan sebuah proses yang membantu menumbuhkan dan mengembangkan. Pendidikan juga berarti proses pengembangan berbagai macam potensi yang ada dalam diri manusia ${ }^{8}$. Istilah karakter berasal dari character berasal dari kata charassein yang artinya 'mengukir corak yang tetap dan tidak terhapuskan'. Watak atau karakter merupakan perpaduan dari segala tabiat manusia yang bersifat tetap sehingga menjadi tanda khusus untuk membedakan orang yang satu dengan yang lain ${ }^{9}$. Dalam dunia perbankan Character adalah keadaan watak dari nasabah baik dalam kehidupan pribadi maupun dalam lingkungan usaha. Kegunaan dari penilaian ini adalah untuk mengetahui

7 Siti Malikhah Towaf, "Pendidikan karakter pada matapelajaran ilmu pengetahuan sosial," Jurnal Ilmu Pendidikan 20, no. 1 (2014): 75-85.

8 Muhammad Asrofi, "Peran pondok pesantren fadlun minalloh dalam menanamkan pendidikan karakter santri di wonokromo pleret bantul" (Yogyakarta: Fakultas Tarbiyah Dan Keguruan, UIN Sunan Kalijogo, 2013).

9 Kristi Wardani et al., "Peran Guru Dalam Pendidikan Karakter Menurut Konsep Pendidikan Ki Hadjar Dewantara," no. November (2010): 8-10. PEMBENTUKAN KARAKTER SISWA MELALUI PENDIDIKAN BERBASIS 
sampai sejauh mana kemauan nasabah untuk memenuhi kewajiban (willingness to pay) sesuai dengan perjanjian yang telah ditetapkan ${ }^{10}$. Prof. Hamka memberikan gambaran tentang sosok manusia yang pandai tapi tidak memiliki pribadi yang unggul:"Banyak guru, dokter, hakim, insinyur, banyak orang yang bukunya satu gudang dan diplomanya segulung besar, tiba dalam masyarakat menjadi "mati", sebab dia bukan orang masyarakat. Hidupnya hanya mementingkan dirinya, diplomanya hanya untuk mencari harta, hatinya sudah seperti batu, tidak mampunyai cita-cita, lain dari pada kesenangan dirinya. Pribadinya tidak kuat. Dia bergerak bukan karena dorongan jiwa dan akal. Kepandaiannya yang banyak itu kerap kali menimbulkan takutnya. Bukan menimbulkan keberaniannya memasuki lapangan hidup"11." Dr. Ratna Megawangi "Pendidikan karakter" adalah pendidikan untuk membentuk kepribadian seseorang melalui pendidikan budi pekerti, yang hasilnya terlihat dalam tindakan nyata seseorang, yaitu tingkah laku yang baik, jujur bertanggung jawab, menghormati hak orang lain, kerja keras, dan sebagainya ${ }^{12}$. Karakter dapat diartikan sebagai sifat-sifat kejiwaan, akhlak atau budi pekerti yang membedakan seseorang dari yang lain. Karakter bisa juga berarti tabiat atau watak. Di samping itu, karakter juga dapat dimaknai sebagai cara berpikir dan berperilaku yang khas tiap individu untuk hidup dan bekerja sama, baik dalam lingkup keluarga, masyarakat, bangsa, dan negara.

Mulyasa mengemukakan bahwa pendidikan karakter merupakan penanaman kebiasaan (habit) tentang hal-hal yang baik dalam kehidupan, sehingga seseorang memiliki kesadaran dan pemahaman yang tinggi, serta kepedulian dan komitmen untuk menerapkan kebajikan dalam kehidupan sehari-hari ${ }^{13}$. Kebiasaan ( habit) proses pembiasaan yang merupakan serangkaian kegiatan pembelajaran dan pendampingan dan diharapkan individu mampu memahami, mengalami, dan mengintegrasikan nilai yang ditanamkan dalam proses pendidikan yang dijalaninya ke dalam kepribadiannya. Proses penanaman kebiasaan (habituation) menjadikan siswa atau santri menjadi paham (kognitif) yaitu pemahaman tentang mana yang benar dan salah, mampu merasakan (afektif) yaitu mana nilai yang baik serta yang jelek dan biasa melakukannya (psikomotor). Dengan kata lain, pendidikan karakter harus melibatkan bukan saja aspek "pengetahuan yang baik (moral knowing), akan tetapi juga melibatkan siswa atau santri untuk

${ }^{10}$ Miftachul Ulum, "Risiko Bisnis Dalam Pandangan Syariah,” Jurnal Ummul Quro VIII, no. 2 (2016): 11-25.

${ }^{11}$ Hamka, Pribadi, 10 ed. (Jakarta: Bulan Bintang, 1982).

12 Ratna Megawangi, Semua Berakar Pada Karakter (Jakarta: Lembaga Penerbit FE-UI, 2007).

${ }^{13}$ Fahham, "Character Education in Islamic Boarding School."

386 I Miftachul Ulum 
"merasakan dengan baik atau loving good (moral feeling), kemudian mendorong anak untuk berperilaku yang baik (moral action). Menurut Pusat Bahasa Departemen Pendidikan Nasional, karakter adalah "bawaan, hati, jiwa, kepribadian, budi pekerti, perilaku, temperamen, watak". Sedangkan berkarakter adalah berkepribadian, berperilaku, bersifat, bertabiat, dan berwatak". Individu yang berkarakter baik atau unggul adalah seseorang yang berusaha melakukan hal-hal yang terbaik terhadap Allah, dirinya, sesama, lingkungan, masyarakat, suku bangsa dan negara serta masyarakat internasional pada umumnya dengan mengoptimalkan potensi (pengetahuan) dirinya dan disertai dengan kesadaran, emosi dan motivasinya (perasaannya).

Lebih lanjut pendiri Nahdlatul Ulama, KH Hasyim Asy'ari, dalam kitabnya, Ādabul Ālim wal-Muta'allim, mengutip pendapat Imam al-Syafi'i yang menjelaskan beliau mengejar adab ( tata krama) laksana seorang ibu yang mengejar anak satu-satunya yang hilang. Berikut kutipan Syaikh Hasyim Asy'ari "at-Tawhīdu yūjibul ìmāna, faman lā ìmāna lahū lā tawhīda lahū; walìmānu yūjibu al-syarī'ata, faman lā syarīata lahū, lā ìmāna lahū wa lā tawhīda lahū; wa al-syarī'atu yūjibu al-adaba, faman lā ādaba lahū, lā syarī'ata lahū wa lā ìmāna lahū wa lā tawhīda lahü ${ }^{14}$."

التوحد يوجب الايمان فمن لاايمان له لاتوحد له \# والايمان يوجب الشريعة فمن لاشريعة له له

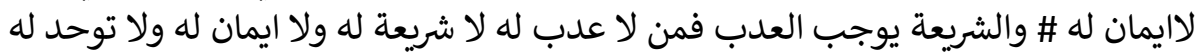

Menurut K.H Hasyim Asy'ari, Tauhid mewajibkan wujudnya iman. Barangsiapa tidak beriman, maka dia tidak bertauhid; dan iman mewajibkan syariat, maka barangsiapa yang tidak ada syariat padanya, maka dia tidak memiliki iman dan tidak bertauhid; dan syariat mewajibkan adanya adab; maka barangsiapa yang tidak beradab maka (pada hakekatnya) tiada syariat, tiada iman, dan tiada tauhid padanya. Dari kaidah tersebut maka dapat dikatakan, jatuh-bangunnya umat suatu negara, tergantung sejauh mana mereka dapat memahami dan menerapkan konsep adab ( tata krama) ini dalam kehidupan mereka. Manusia yang beradab terhadap orang lain akan paham bagaimana mengenali dan mengakui seseorang sesuai harkat dan martabatnya. Hal ini menunjukkan pentingan pembentukan suatu karakter terhadap siswa atau santri, karena mereka disiapkan untuk menjadi penerus eksistensi kehidupan bermasyarakat dan negara.

${ }^{14}$ Hasyim Asy"ari, Ādabul Ālim wal-Muta'allim (Jombang: Maktabah Turats Islamiy, n.d.). 11

PEMBENTUKAN KARAKTER SISWA MELALUI PENDIDIKAN BERBASIS 
Pendidikan karakter di sekolah atau pesantren lebih banyak berurusan dengan penanaman nilai. Penanaman nilai-nilai agar siswa atau santri memiliki gagasan konseptual tentang nilai-nilai pemandu perilaku yang bisa dikembangkan dalam pengembangan karakter pribadinya. Keteladanan memang menjadi salah satu hal klasik bagi hasilnya sebuah tujuan pendidikan karakter bagi siswa atau santri ( guru digugu dan ditiru) maka karakter guru menentukan warna kepribadian siswa atau santri. Nilai keteladanan ini dapat tercermin dari Rasulullah SAW sebagaimana dalam surah Al Ahzab ayat 21

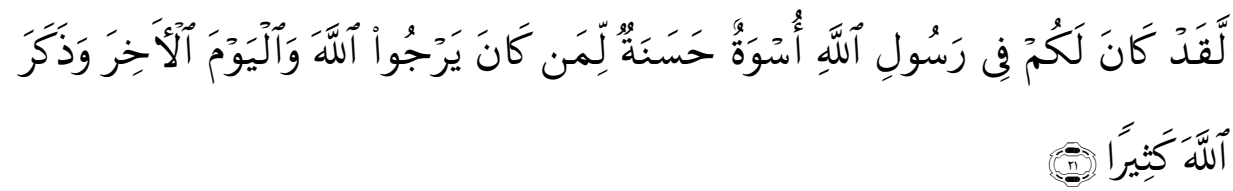

Sesungguhnya telah ada pada (diri) Rasulullah itu suri teladan yang baik bagimu (yaitu) bagi orang yang mengharap (rahmat) Allah dan (kedatangan) hari kiamat dan Dia banyak menyebut Allah ${ }^{15}$.

Pembentukan makna pendidikan karakter sejalan dengan makna pendidikan Undang-Undang Nomor 20 Tahun 2003 tentang Sistem Pendidikan Nasional Pasal 1 adalah "Usaha sadar dan terencana untuk memiliki kekuatan spiritual keagamaan, pengendalian diri, kepribadian, kecerdasan, akhlak, serta keterampilan ". Disebutkan juga bahwa pendidikan nasional adalah "Pendidikan yang berdasarkan Pancasila dan UUD 1945 yang berakar pada nilai-nilai agama, kebudayaan nasional Indonesia". Sukmadinata menjelaskan bahwa terdapat tiga sifat penting dari pendidikan, yakni: "(1) pendidikan mengandung nilai dan memberikan pertimbangan nilai, (2) pendidikan diarahkan pada kehidupan dalam masyarakat, (3) pelaksanaan pendidikan dipengaruhi dan didukung oleh lingkungan masyarakat. ${ }^{16}$ Yang berarti bahwa dalam pelaksanaan pendidikan terkandung unsur-unsur yang merupakan pencerminan dari nilai-nilai moral yang berlaku dan sesuai dengan masyarakat. Siswa harus diarahkan bagaimana semasa mengikuti pendidikan dan menjadi bagian dan dapat menyesuaikan dengan kondisi lingkungan masyarakat. Pendidikan merupakan bagian dari modal untuk dapat hidup dimasyarakat.

David Elkind \& Freddy Sweet Ph.D pendidikan karakter dimaknai sebagai: "character education is the deliberate effort to help people

${ }^{15}$ Departemen Agama RI, al-Qur'an Mushaf dan al-Qur'an Terjemah (Jakarta: Al Huda, 2005).

${ }^{16}$ Yadi Ruyadi dan M Si, "Model Pendidikan karakter nerbasis Kearifan budaya lokal ( Penelitian terhadap Masyarakat Adat Kampung Benda Kerep Cirebon Provinsi Jawa Barat untuk Pengembangan Pendidikan Karakter di Sekolah )," in Proceedings of The 4th International Conference on Teacher Education; Join Conference UPI \& UPSI (Bandung, 2010), 576-594.

388 I Miftachul Ulum 
understand, care about, and act upon core ethical values. When we think about the kind of character we want for our children, it is clear that we want them to be able to judge what is right, care deeply about what is right, and then do what they believe to be right, even in the face of pressure from without and temptation from within". dijelaskan bahwa pendidikan karakter adalah segala sesuatu yang dilakukan guru, yang mampu mempengaruhi karakter peserta didik. Guru membantu membentuk watak peserta didik. Hal ini mencakup keteladanan bagaimana perilaku guru, cara guru berbicara atau menyampaikan materi, bagaimana guru bertoleransi, dan berbagai hal terkait lainnya $^{17}$. Keteladan ini berarti bahwa siswa akan bercermin apa yang dilihat, dirasa ,dialami, dan apa yang dihadapi dalam pergaulan sehari-hari. Nuansa keakraban guru dan lingkungan akan menjadi penentu bagaimana karakter siswa atau santri akan terbentu. Nilai-nilai karakter dapat tercermin dalam sebuah nilai-nilai karakter dasar berupa cinta kepada Allah dan ciptaanNya (alam dengan isinya), tanggung jawab, jujur, hormat dan santun, kasih sayang, peduli, dan kerjasama, percaya diri, kreatif, kerja keras, dan pantang menyerah, keadilan dan kepemimpinan; baik dan rendah hati, toleransi, cinta damai, dan cinta persatuan. Mendasarkan pada grand design yang dikembangkan Kementrian Pendidikan Dasar dan Menengah secara psikologis dan sosial kultural pembentukan karakter dalam diri individu merupakan fungsi dari seluruh potensi individu manusia (kognitif, afektif, konatif, dan psikomotorik) dalam konteks interaksi sosial kultural (dalam keluarga, sekolah, dan masyarakat) dan berlangsung sepanjang hayat. Konfigurasi karakter dalam konteks totalitas proses psikologis dan sosial kultural tersebut dapat dikelompokkan dalam; Olah Hati (Spiritual and emotional development), Olah Pikir (intellectual development), Olah Raga dan Kinestetik (Physical and kinestetic development), dan Olah Rasa dan Karsa (Affective and Creativity development).

Muchlich menyebutkan bahwa ada beberapa pendekatan yang dapat digunakan dalam implementasi pendidikan karakter, yakni pendekatan penanaman nilai, pendekatan perkembangan moral, pendekatan analisis nilai, pendekatan klarifikasi nilai, dan pendekatan pembelajaran berbuat. Pendekatan penanaman nilai pendekatan yang tepat digunakan dalam pendidikan karakter di Indonesia ${ }^{18}$. Pelaksanaan pendidikan karakter dapat

17 Muhammad Walid, "Model Pendidikan Karakter di Perguruan Tinggi Agama Islam (Studi Tentang Pendidikan Karakter Berbasis Ulul albab di Universitas Islam Negeri Maulana Malik Ibrahim Malang)," Jurnal eL-Qudwah 1, no. 5 (2011): 115-156.

${ }^{18}$ Fahham, "Character Education in Islamic Boarding School." PEMBENTUKAN KARAKTER SISWA MELALUI PENDIDIKAN BERBASIS 
dilakukan secara terintegrasi dalam setiap keseharian, baik melalui pembelajaran dikelas maupun dilingkungan luar kelas, sehingga yang memungkin kegiatan ini bisa terkontrol hanya pendidikan yang berada di dalam pondok pesantren

\section{B. Pembentukan Karakter Siswa atau Santri di Pondok Pesantren}

Berbicara tentang santri sesuatu yang menarik dan tidak akan habis jika kita ungkapkan, betapa tidak, bagi anda yang pernah nyantri dan pernah menikmati jadi santri pasti masih teringat dengan dengan teman-teman yang dulu dalam seperjuangan di pondok pesantren. Menarik untuk diperbincangkan karena pesantren tumbuh dan berkembang pada masyarakat Islam, munculnya pesantren di Indonesia telah melewati perjalanan panjang yang mana negara Indonesia, negara yang penduduknya muslim terbesar, Indonesia juga memiliki paling banyak pesantren di dunia, serta banyak ilmuan dan tokoh nasional pernah belajar di pesantren. Kepercayaan masyarakat sebagai wali murid untuk menyekolahkan dan nyantri di pesantren tetap konsisten bahkan semakin meningkat, apalagi program pendidikan pun sekarang lebih cenderung untuk menggunakan konsep pesantren yaitu berada diasrama. Kepercayaan masyarakat terhadap pesantren bukan tanpa alasan, tapi lebih kepada tujuan pembentukan karakter siswa atau santri. Keseharian hidup pondok pesantren dimulai setelah bangun tidur sampai akan menjelang tidur sudah dimulai dengan pembiasaan yang baik. Kegiatan pengajian baik kitab kuning maupun musyawarah sudah menjadi kegiatan rutin tanpa harus terpaksa dilakukan, santri sudah dapat menikmati dengan perasaan senang. Kegiatan ibadah dilakukan dengan tertib waktu seperti melaksanakan sholat berjamaah, kegiatan sosial kemasyarakat dilaksanakan dengan gotong royong menambah keharmonisan dalam hidup bermasyarakat. Kesemua kegiatan tersebut mencerminkan kualitas pendidikan berkarakter. Pembiasaan kehidupan dengan pendekatan kegiatan keagamaan sangat kuat sekali pembentukan dalam berkarakter. Santri disuguhkan kegiatan keagamaan dalam menjalankan ibadah. Setiap kegiatan penuh makna pahala dan bernilai ibadah, inilah yang menjadi kunci manusia untuk tetap selalu menjalankan aktifitas dan bernilai ibadah. Menanamkan nilai-nilai agama merupakan pangkal akhir dalam kehidupan bermasyarakat, sehingga nilai moral seseorang sangat tergantung bagaimana seseorang memaknai hidup dalam kontek beragama dalam menjalankan ibadahnya.

Hasil penelitian Syukri Fahtudin yang berjudul: "Pembentukan kultur akhlak mulia melalui pembelajaran pendidikan agama Islam dengan model penilaian self and peer assesment di kalangan mahasiswa Fakultas Teknik $U N Y^{\prime \prime}$. Karakter pada orang dewasa sudah terbentuk sejak anak-anak dan 390 I Miftachul Ulum 
remaja. Pendidikan karakter melalui model-model pembelajaran belum tentu efektif dilaksanakan. Pendidikan karakter orang dewasa yang sesuai adalah melalui peningkatan kesadaran untuk berperilaku positif dan evaluasi diri (self evaluation). Pendidikan karakter lebih efektif jika muncul dari kesadaran dirinya sendiri, bukan pengaruh dari orang lain. Bentuk-bentuk pendidikan karakter antara lain dilakukan melalui: ceramah dan pengajian, pengangkatan tema pendidikan karakter dalam forum seminar, diskusi, media masa, film, penulisan karya ilmiah yang bertema pendidikan karakter, belajar dari pengalaman hidup orang lain, dsb. Banyak pengalaman orang- orang yang berkarakter negatif dapat berubah menjadi positif setelah mereka dihadapkan pada permasalahan hidup dan belajar dari kehidupan orang lain yang sedang mengalami masalah ${ }^{19}$. Hal penelitian ini menunjukkan sejatinya bahwa pendidikan karakter ditunjukan pada kegiatan masa anak-anak. Pembentukan karakter melalui suatu lingkungan yang baik dan selalu berkesinambungan akan membentuk pribadi siswa atau santri yang yang baik untuk masa yang akan datang. Salah satu pembentukan lingkungan dengan pendidikan santri atau siswa melalui pondok pesantren memang telah teruji, pola pendidikan di pesantren sangat khas dan menjadi pembeda dengan lembaga pendidikan yang lain. Pola ini lebih menggambarkan bagaimana tradisi di lingkungan pesantren yang menekankan pada etika santri dalam belajar di pesantren ${ }^{20}$. Kita tahun corak pesantren sangat identik dengan pengasuh atau pendiri pesantren. Jiwa dan karakter pengasuh pesantren turut andil dalam membentuk jiwa santri, namun secara keseluruhan pesantren mempunyai karakter dan jiwa yang sama dalam syiar agama. Nilainilai esensial adalah nilai-nilai yang dikontruk oleh perintis pesantren dan menjadi bagian dari kepribadian yang tidak terpisahkan antara dirinya dan pesantren. Istilah karakter adalah nilai "value" (Inggris) atau "valere" (Latin) yang berarti harga. Nilai adalah sesuatu yang bernilai atau sesuatu yang berharga. Nilai dapat diartikan sebagai penghargaan terhadap suatu hal yang dapat menjadi dasar penentu tingkah laku manusia karena sesuatu itu menyenangkan (peasent), berguna (useful), memuaskan (stifing), menguntungkan (pro-fitable), menarik (interesting), dan merupa-kan

${ }^{19}$ Endang Mulyatiningsih, "Analisis Model-Model Pendidikan Karakter Untuk Usia Anak-Anak, Remaja Dan Dewasa" (n.d.): 1-18.

${ }^{20}$ Kamin Sumardi, "Portrait of character education in salafiah boarding school."

PEMBENTUKAN KARAKTER SISWA MELALUI PENDIDIKAN BERBASIS 
keyakinan (belief).Contoh dari nilai ini adalah kejujuran, tanggung jawab, keikhlasan, toleransi, harmoni, dan lain-lain ${ }^{21}$.

Secara keseluruhan dalam pesantren tercermin jiwa nilai (1) keikhlasan; (b) kesederhanaan; (c) kesanggupan menolong diri sendiri atau berdikasi; (4) ukhuwwah diniyah yang demokratis antara santri; dan (e) bebas $^{22}$. Jiwa keikhlasan adalah pangkal dari segala jiwa pondok dan dilakukan dengan niat semata-mata ibadah, lillah, ikhlas hanya karena Allah semata. Pendidikan keilhlasan diwujudkan melalui keteladanan para pendiri pondok dengan mewakafkan pondok seluruhnya. Kesederhana di pondok pesantren tidak berarti pasif atau nrimo, tidak juga berarti miskin dan melarat. Justru dalam jiwa kesederhanaan itu terdapat nilai-nilai kekuatan, kesanggupan, ketabahan, dan penguasaan diri dalam menghadapi perjuangan hidup. Pendidikan kesederhanaan yang diajarkan antara lain: kesederhanaan dalam berpakaian, potongan rambut, makan, tidur, berbicara, bersikap, dan bahkan dalam berpikir. Kesanggupan menolong diri (berdikari ) tidak saja berarti bahwa santri sanggup belajar dan berlatih mengurus segala kepentingannya sendiri, tetapi pondok pesantren itu sendiri sebagai lembaga pendidikan juga harus sanggup berdikari sehingga tidak pernah menyandarkan kehidupannya kepada bantuan atau belaskasihan pihak lain. Jiwa persaudaraan (ukhuwwah) ini menjadi dasar interaksi sistem dalam antara santri, kyai, dan guru kehidupan pesantren, dari sinilah tumbuh kerelaan untuk saling berbagi dalam suka dan duka, hingga kesenangan dan kesedihan dirasakan bersama. Santri ditanamkan dalam kebersamaan dan tolong-menolong, seperti mengurusi organisasi, olah raga, khitobiyah dan lain-lain. Bebas dalam berpikir dan berbuat, bebas dalam menentukan masa depan, bebas dalam memilih jalan hidup, dan bahkan bebas dari berbagai pengaruh negatif dari luar, masyarakat. Jiwa bebas ditanamkan kepada santri agar menjadikan santri berjiwa besar dan optimis dalam menghadapi segala kesulitan. Dari pola kegiatan tersebut diatas maka implikasi dari pembentukan santri yang mempunyai kualifikasi unggul seperti itu adalah pengetahuan yang diperoleh santri tidak sekedar terwujud dalam ranah kognitif saja, melainkan juga terbentuk dalam sikap dan perbuatan seharihari. Maka suasana pembentukan lingkungan dipesantren menjadi penetu dalam mewujudkan pendidikan yang berkarakter. Kegiatan yang tercermin melalui pembiasaan yang baik akan memunculkan sikap mental positif dalam diri santri sehingga akan membentuk sebuah sikap kolektivitas yang menjadi

${ }^{21}$ Imam Machali Mangun Budiyanto, "Pembentukan Karakter Mandiri Melalui Pendidikan Agriculture Di Pondok Pesantren Islamic Studies Center Aswaja Lintang Songo Piyungan Bantul Yogyakarta," Jurnal Pendidikan Karakter 4, no. 2 (2014): $108-122$.

${ }^{22}$ Fahham, "Character Education in Islamic Boarding School." 
dasar terwujudnya culture value system (sistem nilai budaya). Sistem nilai budaya tidak saja berfungsi sebagai suatu pedoman tetapi juga suatu pendorong kelakuan santri dalam kehidupannya, sehingga berfungsi juga sebagai suatu sistem tata kelakuan, malahan sebagai salah satu sistem tata kelakuan yang tertinggi diantara yang lain, seperti hukum adat, aturan sopan santun dan sebagainya. ${ }^{23}$

Sebagai gambaran kondisi bagaimana pendidikan karakter dapat terbentuk di pondok pesantren berikut ini kami gambarkan kegiatan aktifitas di Pondok Pesantren Sunan Drajat Banjarwati Paciran Lamongan. Pesantren ini telah berdiri hampir 41 tahun yang lalu tepatnya pada tahun 1977 dibawah pengasuh Prof Dr. KH. Abdul Ghofur dengan jumlah santri 11.000 orang. Kegiatan lembaga pendidikan mulai dari Pendidikan anak Usia Dini ( PAUD) Mu'awanah, MI Mu'awanah, SMPN 2 Paciran, MTs Sunan Drajat, Madrasah Mu'allimin Mu'allimat, MA Ma'arif 7 , SMK Sunan Drajat Lamongan dan Institut Pesantren Sunan Drajat Lamongan. Disamping lembaga formal juga lembaga non formal yang merupakan bagian dari lembaga di pondok pesantren, yaitu Madrasah diniyah yang meliputi 3 kelompok jenjang, Madrasatul Qur'an, dan Lembaga Pengembangan Bahasa Asing. Disamping kegiatan pendidikan juga kegiatan keorganisasian yang meliputi forum kajian dan forum alumni. Yayasan Pondok Pesantren Sunan Drajat juga mengembangkan unit usaha sebagai bagian dari kemandirian santri meliputi pabrik air minum Aidrat, Persada TV, Persada FM, Raisa Travel Haji dan Umroh, pabrik pupuk SDL, penambangan, konveksi, percetakan, pertokoan, jus mengkudu sunan dan sebagainnya.

Kegiatan santri dimulai sebelum subuh mulai jam 03.30 WIB dengan melaksanakan sholat tahajut, kegiatan rutinitas diharapkan santri dapat menguatkan keimanan melalui sholat tahajut. Dilanjutkan dengan dengan sholat subuh berjamaah, setelah sholat subuh tepatnya santri harus sudah berada di aula asrama atau ruang kelas untuk mengikuti kegiatan pengajian salaf ( kitab kuning ) namun sebelum pelaksanaan pengajian kitab salaf, santri dibiasakan dengan membaca surat Waqiah yang mana keutamaannya agar perekonomian keluarga santri lebih baik. Kegiatan pengajian kitab berlangsung 45 menit, santri dilanjutkan persiapan untuk mengikuti kegiatan sekolah formal sesuai dengan jenjang santri. Selama persiapan santri harus sudah mandi dan sarapan pagi bersama. Dengan jumlah santri yang begitu banyak santri harus dapat menyesuaikan dan memanfaatkan waktu sebaikbaiknya dengan fasilitas yang juga terbatas. Pembiasaan yang dirasakan

${ }^{23}$ M. Syaifuddien Zuhriy, "Budaya Pesantren Dan Pendidikan Karakter Pada Pondok Pesantren Salaf," Jurnal Walisongo 19, no. 2 (2011): 287-310.

PEMBENTUKAN KARAKTER SISWA MELALUI PENDIDIKAN BERBASIS 
santri bagian untuk menjadi santri atau siswa yang disiplin, dapat memanfaatkan waktu yang sebaik-baik termasuk tanggung jawab mengatur dirinya sendiri yang mana kegiatan dipesantren baru dipagi hari. Selanjutnya kegiatan di lembaga pendidikan sesuai jenjang formal berlangsung sampai jam 12.40 WIB dan diakhiri dengan sholat jama'ah sholat dhuhur dalam pantauan lembaga formal. Santri kembali keasrama pondok untuk persiapan makan bersama dan juga siap siap antri. Pada jam 15.00 WIB santri harus sudah berada di masjid untuk melaksanakan sholat ashar berjamaah. Setelah sholat ashar tepatnya jam 15.30 WIB santri sudah harus berada diruang kelas untuk mengikuti kegiatan madrasah diniyah dan berlansung sampai jam 17.00 WIB. Sebagai santri harus mampu memanfaatkan waktu antara setelah sholat dhuhur sampai menjelang ashar srelama 90 menit untuk kegiatan makam siang, mandi dan istirahat sebelum sholat ashar. Setelah kegiatan di madrasah diniyah santri sudah dihadapkan pada kegiatan dimasjid untuk menunggu datangnya sholat maghrib berjama'ah Dimasjid santri diwajibkan membaca surat Yasin dan bacaan isthighosah yang bertujuan diberi keselamatan bagi dirinya dan keluarganya. Kegiatan ini berlangsung setiap hari , khusus pada hari Selasa dan Jum'at kegiatan madrasah diniyah libur, sebagai gantinya santri diberi kesempatan untuk mengapresiasikan hobi olahraga atau kesenian dalam wadah organisasi atau unit yang telah diselengarakan. Kegiatan seni dan olahraga merupakan bagian pembentukan santri untuk menyalurkan bakat dan kreatifitas yang dimiliki, serta bagaimana mampu mengembangkan kehidupan berorganisasi dalam kelompok unit kegiatan. Setelah kegiatan sholat jamaah santri sudah dihadapkan pada kegiatan madrasatul qur'an, kegiatan ini berjengjang sesuai dengan kemampuan masing-masing. Tingkatan kelas ditentukan oleh kemampuan santri tidak memandang umur, kecil atau besarnya santri. Kegiatan ini berlangsung singkat sampai sholat isya' atau jam 19.00 WIB. Ketika sholat isya dimulai santri harus sudah dimasjid untuk mengikuti sholat jama'ah. Setelah sholat isya santri harus mempersiapkan kegiatan pengajian kitab salaf atau mengikuti program pengembangan bahasa, kegiatan ini berlangsung mulai jam 19.45 -21.00 WIB. Kegiatan pada malam hari terkhusus hari Senin malam selasa pada kegiatan pengajian salaf atau pengembangan diganti dengan kegiatan di asrama pembacaan sholawat nabi dan khitobiyah. Kegiatan sholawat ditujukan untuk menciptakan santri yang benar benar cinta dan rindu kepada rosulullah, dan kegiatan khitobiyah memberikan modal bagi santri untuk berani tampil di hadapan santri dalam berdakwah. Santri di bekali bagaimana menyampaikan orasi atau berceramah sebagai modah dimasyarakat. Khusus kamis malam jum'at mulai sholat maghrib santri sudah melakukan kegiatan tahlil dan istghosah sampai jam 21.00 WIB . Kegiatan ini sebagai penguatan keimanan kepada santri betapa pentingnya kegiatan berdoa. Pembiasaan ini bagian dari kegiatan 394 I Miftachul Ulum 
pembentukan karakter, dan hal ini hanya bisa dilakukan di pondok pesantren, salah satunya di pondok pesantren Sunan Drajat Banjarwati Paciran Lamongan. Pada hari Jum'at setelah sholat subuh santri sudah dibiasakan untuk berjiarah kemakam, kegiatan jiarah ini dilakukan di makam pejuang Islam yaitu makam Mbah Sunan Mayang Madu yang masih berada di lingkungan pesantren, kegiatan ini bertujuan membiasakan santri untuk selalu ingat bahwa manusia pada akhirnya akan kembali kepada Allah SWT, bahwa manusia penuh dengan kekurangan, manusia untuk selalu rendah diri dan tidak boleh sombong. Setelah kegiatan jiarah kemakam santri bersiap siap untuk menuju kemasjid tepatnya jam 07.00 untuk mengikuti pengajian salaf yang langsung dipimpin oleh pengasuh pesantren Prof. Dr. KH. Abdul Ghofur. Kegiatan di masjid ini merupakan bagian langsung dari komunikasi antara santri dan pengasuh. Santri diberi kesempatan untuk bertanya melalui selembar kertas dengan menuliskan pertanyaan, pengasuh secara langsung membacakan pertanyaan dan menjawabnya. Nuasa komunikasi antara santri dan pengasuh merupakan jembatan pembentukan dalam pembentukan karakter, bagaimana etika santri atau siswa dalam menyampaikan suatu ide ?, bagaimana mengkomunikasikan suatu permasalahan ?.

Pembiasaan kegiatan di Pondok Pesantren Sunan Drajat Banjarwati Paciran Lamongan merupakan sebagian dari pembentukan karakter santri. Dalam kegiatan kemandirian Pondok Pesantren Sunan Drajat memiliki berbagai macam bentuk usaha bisnis. Hal ini merupakan gambaran pendidikan karakter santri untuk membentuk jiwa wirausaha, bagaimana mengelola sebuah usaha ?, bagaimana menjadi orang berjiwa wirausaha ?, bagaiman hidup mandiri dengan membuka usaha ?. Santi yang bermukim di sebuah asrama merupakan bentuk pembentukan karakter, dimana santri sudah dihadapkan bagaimana mereka mengatur, mengelola kehidupan sehari-hari secara mandiri ?. Kemandirian dalam mengatur hidup merupakan bekal kehidupan yang akan datang. Bagaimana santri dapat menyesuaikan dan beradaptasai dengan santri yang tentu berbeda dari kelompok masyarakat baik suku, ras, sosial ekonomi dan kararakter yang berbeda-beda ?. Terlepas dari keterbatas baik fasilitas mau kondisi apapun dalam pondok pesantren, bahwa pesantren telah menanamkan unsur-unsur pembentukan karakter santri atau siswa dalam menghadapai kehidupan yang akan datang.

\section{KESIMPULAN}

Karakter pondok pesantren tidak dapat lepas dari karakter dari para pendiri pesantren. Pendiri sekaligus pengasuh menjadi bagian sentral di pondok pesantren, maka ketika seorang pengasuh mengambil keputusan apapun seorang santri hormat dan tunduk. Pengasuh telah menjadi sumber imajinasi, PEMBENTUKAN KARAKTER SISWA MELALUI PENDIDIKAN BERBASIS 
sumber insiparasi, aktifitas dan keseharian pengasuh telah menjadi teladan , pengasuh menjadikan dirinya magnet bagi santri sehingga santri ingin meneladani apa yang dilakukan pengasu. Lingkungan pesantren dan aktifitas santri sehari-hari telah membentuk karakter dan jiwa santri untuk mandiri.

\section{DAFTAR RUJUKAN}

Asrofi, Muhammad. "Peran pondok pesantren fadlun minalloh dalam menanamkan pendidikan karakter santri di wonokromo pleret bantul." Yogyakarta: Fakultas Tarbiyah Dan Keguruan, UIN Sunan Kalijogo, 2013.

Departemen Agama RI. al-Qur'an Mushaf dan al-Qur'an Terjemah. Jakarta: Al Huda, 2005.

Endang Mulyatiningsih. "Analisis Model-Model Pendidikan Karakter Untuk Usia Anak-Anak, Remaja Dan Dewasa" (n.d.): 1-18.

Fahham, A Muchaddam. "Character Education in Islamic Boarding School." Aspirasi 4, no. 1 (2013): 29-45.

Hamka. Pribadi. 10 ed. Jakarta: Bulan Bintang, 1982.

Hasyim Asy"ari. Ādabul Ālim wal-Muta'allim. Jombang: Maktabah Turats Islamiy, n.d.

Kamin Sumardi. "Portrait of character education in salafiah boarding school." Jurnal Pendidikan Karakter 2, no. 3 (2012): 280-292.

M. Dawam Rahardjo. Pergulatan Dunia Pesantren. Jakarta: P3M, 1985.

M. Syaifuddien Zuhriy. "Budaya Pesantren Dan Pendidikan Karakter Pada Pondok Pesantren Salaf." Jurnal Walisongo 19, no. 2 (2011): 287-310.

Mangun Budiyanto, Imam Machali. "Pembentukan Karakter Mandiri Melalui Pendidikan Agriculture Di Pondok Pesantren Islamic Studies Center Aswaja Lintang Songo Piyungan Bantul Yogyakarta." Jurnal Pendidikan Karakter 4, no. 2 (2014): 108-122.

Miftachul Ulum. "Eksistensi Pendidikan Pesantren: Kritik Terhadap Kapitalisasi Pendidikan." TA"LIM : Jurnal Studi Pendidikan Islam 1, no. 2 (2018): 20-37.

396 I Miftachul Ulum 
- - - "Risiko Bisnis Dalam Pandangan Syariah." Jurnal Ummul Quro VIII, no. 2 (2016): 11-25.

Ratna Megawangi. Semua Berakar Pada Karakter. Jakarta: Lembaga Penerbit FE-UI, 2007.

Riris Nur Rohmawati. "Hubungan Antara Faktor Pengetahuan Dan Perilaku Dengan Kejadian Skabies Di Pondok Pesantren Al-Muayyad Surakarta." Surabaya: Fakultas IImu Kesehatan Universitas Muhammadiyah Surakarta, 2010.

Ruyadi, Yadi, dan M Si. “Model Pendidikan karakter nerbasis Kearifan budaya lokal ( Penelitian terhadap Masyarakat Adat Kampung Benda Kerep Cirebon Provinsi Jawa Barat untuk Pengembangan Pendidikan Karakter di Sekolah )." In Proceedings of The 4th International Conference on Teacher Education; Join Conference UPI \& UPSI, 576-594. Bandung, 2010.

Towaf, Siti Malikhah. "Pendidikan karakter pada matapelajaran ilmu pengetahuan sosial." Jurnal IImu Pendidikan 20, no. 1 (2014): 75-85.

Walid, Muhammad. "Model Pendidikan Karakter di Perguruan Tinggi Agama Islam (Studi Tentang Pendidikan Karakter Berbasis Ulul albab di Universitas Islam Negeri Maulana Malik Ibrahim Malang)." Jurnal eLQudwah 1, no. 5 (2011): 115-156.

Wardani, Kristi, Kata Kunci: Guru, Pendidikan Karakter, Konsep Pendidikan, dan Ki Hadjar Dewantara. "Peran Guru Dalam Pendidikan Karakter Menurut Konsep Pendidikan Ki Hadjar Dewantara," no. November (2010): 8-10. 